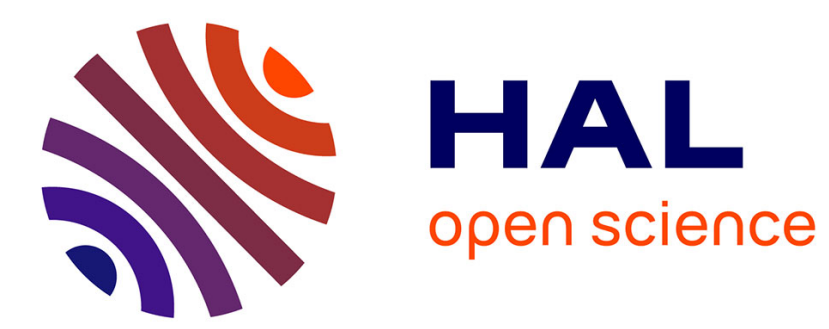

\title{
Classifying matters
}

John Kirk

\section{To cite this version:}

John Kirk. Classifying matters. European Journal of Cultural Studies, 2007, 10 (2), pp.225-244. 10.1177/1367549407069064. hal-00571530

\section{HAL Id: hal-00571530 https://hal.science/hal-00571530}

Submitted on 1 Mar 2011

HAL is a multi-disciplinary open access archive for the deposit and dissemination of scientific research documents, whether they are published or not. The documents may come from teaching and research institutions in France or abroad, or from public or private research centers.
L'archive ouverte pluridisciplinaire HAL, est destinée au dépôt et à la diffusion de documents scientifiques de niveau recherche, publiés ou non, émanant des établissements d'enseignement et de recherche français ou étrangers, des laboratoires publics ou privés. 


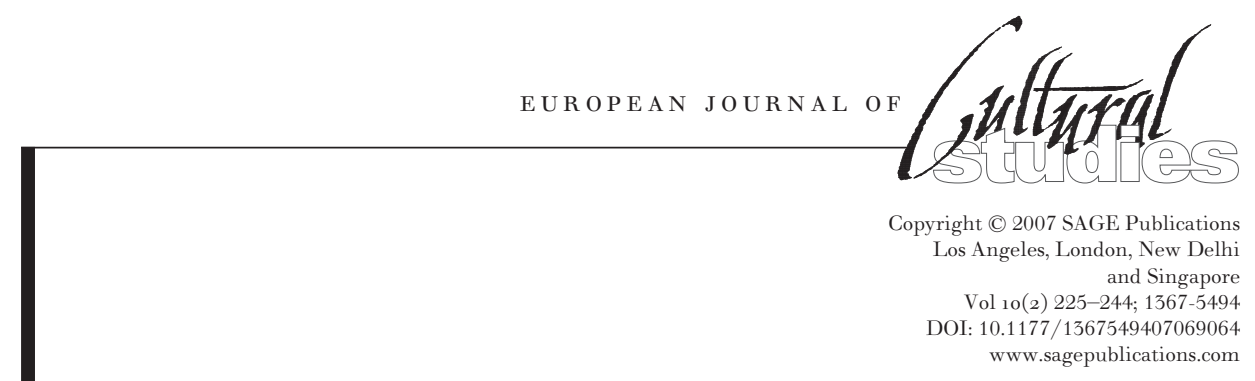

\title{
Classifying matters
}

\author{
John Kirk \\ London Metropolitan University
}

ABSTRACT Although the rhetoric of classlessness has never quite found the resonance that it has in North American mythology, there have been key moments in British culture when this proposition occupied a hegemonic role in sociological and cultural commentary. In recent years this position has strengthened so that a range of factors have displaced class and produced a more confident and strident rhetoric of classlessness in British society than heard hitherto. A focus in academic disciplines on identity politics and the rise of the consumer has meant a retreat from class analysis in a range of disciplines. This article aims to engage with ideas of classlessness through a reading of Beverley Skeggs' recent Class, Self, Culture. It ends by making some suggestions on how class analysis might be resituated once more at the centre of cultural analysis.

KEYWORDS class, culture, identity, representation, self

Employing the language of class is always a potentially controversial exercise, and this is never more so than in the British context. Indeed, as David Cannadine has pointed out in his book, Class in Britain (2000), there exists a wide belief 'that the British are obsessed with class in the way that other nations are obsessed with food or race or sex or drugs or alcohol' (2000: ix). This obsession takes contrasting trajectories, producing a range of contradictory discourses on the topic. From Marx to Margaret Thatcher, the subject of class - usually in the shape of the working class has rested like a nightmare on the brains of the living. This may be one good reason why invoking the idea of class invariably provokes its contrary - the notion of classlessness, or the end of class. Thus, although the rhetoric of classlessness has never quite found the resonance that it has in North American mythology, there have been key moments in British society when this proposition has occupied a hegemonic role in sociological and cultural commentary, while finding a different (if still insistent) register in wider culture. In recent years this position has strengthened so that a range of factors have displaced class, and produced a more confident and strident rhetoric of classlessness in British society than heard hitherto. Now, in the 
western world, ideas of consumption and of the sovereign consumer are projected onto all aspects of social life, it seems: from health to education, politics to personal relationships. This is reflected, too, in the intellectual marketplace where studies of consumerism abound, providing a focus of research in such disciplines as cultural studies where, it sometimes seems, the consumer has emerged since the 1980 s as a potential political subversive in their own right. Among all this activity, the dialectical counterpart of the consumer - what was once called 'the producer' - has all but disappeared. A corollary of this has been the demise, in cultural studies and cognate disciplines - as well as in mainstream political discourse - of significant interest in the concept and experience of class. Indeed, there has emerged an insistence on a kind of classlessness seen to be paradigmatic of the new postmodern consumerist milieu.

In a return to a serious analysis and understanding of class, particularly working-class identity, Beverley Skeggs' Class, Self, Culture (2004) provides a sharply focused critique of the 'end of class' arguments found in the field of cultural studies and sociology in particular - positions which have gained ground since the 1980s. Skeggs is concerned with the making of class through culture, exploring the 'hidden' ways in which class is figured in society. She suggests that class 'is dynamic, produced through conflict and fought out at the level of the symbolic' (2004: 5), thus insisting on multiple sites of class construction. The making of class, then, is a process of production and positioning, and it is within dominant strategies of projection and appropriation, through relations of representation and exchange, that class is fixed over time and in space. Skeggs explores this idea by utilizing Bourdieu's conceptions of capital: the economic, cultural, social and symbolic, revealing how struggles within these taxonomies of value produce sites of exploitation and inequality. So while class remains an economic positioning - she recognizes class relations as in part an objective position within relations of production - the concepts of exploitation, investment and value are extended and reoriented to enable a consideration of class identity as a cultural, ideological and historical articulation, with its current manifestations euphemistically employed both to disguise and reinforce class privilege and subordination. By examining a range of areas which articulate class relations, Skeggs endeavours to 'explore class struggle made through culture in which value is continually contested' (2004: 187). This article aims to engage with some of the book's central ideas, and it does so by focusing on three main periods in British history: the 19th century, the late 1950s and early 1960s and the closing two decades of the 20 th century. The way in which working-class subjectivity is depicted, displaced and denied in various modes of writing will be the central concern here. The article concludes by insisting on the continued significance of class for understanding political, economic and cultural formations. 


\section{Locating the self and class in 19th-century discourse}

Ideas of the self and personhood form the core of Skeggs' study, although this construction is placed within classed contexts and rigorously historicized. Skeggs argues that to establish an identity involves locating a constitutive Other. In this dialectical process, the self is regarded 'as a part of a system of inscription, exchange, perspective and value-laden attribution ... shaped by the dominant symbolic' (2004: 9), so that personhood is 'always historically and spatially located, especially via national spaces' (2004: 20). And, we might add, made manifest by and through a set of conventions and the available languages whereby a culture works to articulate itself. However, these languages are not separate from wider social processes. Skeggs shows how the rise of capitalism and the dominance of exchange relations shape class relations in the 19th century, figuring exploitation as a key process in such transactions. Paradoxically, this exploitation is disguised in much bourgeois discourse by the requirement to universalize exchange as part of the ideological work of an emergent bourgeoisie intent on transcending class 'by assuming the essential equality of all in the market place' (2004: 29), a space that is perceived as a neutral site for the individual's commercial activity and a public space to display their (usually his) moral probity and status value. Both self and class can be seen to be produced through exchange relationships in this way, in turn normalizing market imperatives and rationalizing the subject of consumption, providing a new concept of self, shaped by notions of interest and value. The bourgeois ideal is established in terms of what Skeggs calls 'personhood' (2004: 46), while those outside this representation (the working class and women; not forgetting colonized peoples) constitute the irrational Other, associated more with the excessive or ugly body of dubious value rather than the rational and calculating Mind. Skeggs provides textual evidence of these tendencies, drawing on a range of discourses which disclose strategies of codification and classification - ideologies embedded in such 19th-century concepts as the 'social body' which, according to Skeggs, operate alongside exchange to circumscribe, discriminate and fix (2004: 36).

This can be identified in symbolic production as diverse as the 19th-century novel to formalized economic or political tracts, in which conceptions of class gel not only along economic lines, but also in cultural and ideological terms. The moral economy of class emerges, whereby the 'degenerate' working class constitutes the cankered part of the social body or body politic, to be labelled and scrutinized and, if need be, tightly controlled. This produces a 'particular version of the self' (2004: 39), in which the middle-class self is characterized as rational and reflexive and the working-class self is seen as primitive and impulsive - ideological positions giving rise at the time to reform initiatives, among other less liberal measures. Skeggs points to the way in which domestic servants 
were 'depicted by the racialised imagery of degradation - of contagion, promiscuity and savagery' (2004: 37), and how the working class were perceived in general by social commentators as a 'race apart', employing the discourses of the 'natural' and 'biological' to fix such difference. Notable here is the strongly gendered (and 'raced') nature of these representations, so that working-class women emblematize all that is potentially threatening to the consolidating capitalist social order. This tendency to fix and discriminate, operating through 'race', gender and class coordinates, can be seen alongside other approaches designed to civilize the lower orders. Such publications as Samuel Smiles' bestselling Self-Help (1859), which produced a particular version of the entrepreneurial self to which the 'respectable' working class and others might subscribe, were modelled on the middle-class ideal. Skeggs could have detailed also the role played by that emergent cultural form, the novel, in shaping perceptions of both self and other for the middle class.

To do this would be to implicate literature as ideology. Indeed, class always has been in some significant senses at the heart of what we call literature in the western world. The attention to class conflict so evident in key 19th-century writing is evidence of this. Entering the 20th century, the preoccupations of literary modernism with style became a way of rejecting and distancing itself from the 'vulgar' trappings of a burgeoning mass culture and lower-class tastes. (Carey, 1992; Huyssens, 1988). More broadly, we might want to highlight the specific ideological function of literature in the field of education as a token of taste and distinction and as a signifier for the more privileged of an access to the type of cultural capital that facilitates social reproduction. Returning to Skeggs' argument, it is possible to suggest that the 19th-century realist novel performed the very function that she outlines above, becoming a kind of moral lodestone for the bourgeoisie, helping to shape responses to social problems which might be resolved only through the ideological work that the realist text undertook in explaining the increasingly 'unknowable community' created by the industrial revolution.

Building on the literary heritage of writers such as Jane Austen and Sir Walter Scott, classic 19th-century fiction came to articulate the growing tensions between class fears, social progress and liberal reform and these anxieties were often inscribed on the very body of the proletarian protagonists through discourses associated with morality and temperance. This tendency is apparent in such classics as Elizabeth Gaskell's (1981[1848]) Mary Barton, published in the revolutionary year of 1848, a time of revolts against tyranny on the continent and the year of publication in Britain of Marx and Engels' Communist Manifesto (1967[1848]). Gaskell's novel is an interesting exception to some of the more ideologically coded moralizing tracts outlined in Skeggs' book that fixed working-class subjectivity as debased. Indeed, Gaskell constructs largely sympathetic portrayals of working-class life, its intimacies and hardships. Where the novel turns 
against her working-class protagonists - while remaining critical of the 'uncaring' middle-class mill owners - comes at the moment that they attempt to articulate and instate an alternative political economy and moral and ideological code of conduct through the demands of Chartism. Thus John Barton, the Chartist organizer, slips from conscientious worker and father to drunken murderer, the culminating act of class antagonism that puts him beyond the pale, thus inscribing him and such actions (not unheard of at the time, although not as widespread as the bourgeoisie believed or feared) under the mark of depravity - essentially in-human, hence Gaskell's references to the workers as an out-of-control Frankenstein monster. Charles Dickens (Hard Times, 1985[1854]), Charlotte Brontë (Shirley, 1991[1849]) and George Eliot (Felix Holt, 1980[1866]), offer similar narrative orientations for depicting the working class in their novels. The workers are easily led by outside agitators, or reveal an overly active class consciousness of their own. Their proximity to polite, middleclass society is either too close and contaminating or too distant and alien. They endure their labour with stoic dignity or pride, or shirk from it at the first available instance.

This brief discussion of literary representations reinforces Skeggs' point quite well. Voicing class fears - or simply, class disdain - by making visible the working-class subject helps to demarcate difference. The site/sight of the Other, particularly at times of social unrest, becomes the proletarian or the poor, the wretched in their slums, the prostitute in the back alley. The middle-class gaze, then, might penetrate the city slums and factory towns not only in the reports of social reformers, but through the pages of the 'engaged' novel. Separated by geographical space and social position, representations of the working class by middle-class novelists, social reformers, social policy legislators and journalists alike all emerge under the sign of excess, confirming Stallybrass and White's view that:

The bourgeois subject continuously defined and redefined itself through the exclusion of what it marked out as the 'low'. Yet that very act of exclusion was constitutive of its identity. The low was internalised under the sign of negation and disgust. (1986: 76)

The fear of contamination was not only psychic or social, but also articulated profound political dimensions. The centripetal forces which attempted to channel the energies of an emergent modernity also had to channel the potentially oppositional powers of a developing working class for fear that men like John Barton might have no investment in bourgeois progress at all.

However, the working class was developing its own political and cultural formations at the same time. This is a significant point that Skeggs, in her analysis of 19th-century discourses on class, tends to gloss over. By so doing she misses an important counter-hegemonic formation striving to represent working-class subjectivity in opposition to those dominant discourses and 
institutional practices shaping and controlling understandings of class. Within two generations Chartism, the first mass political movement of the British working class, had come to fruition, encoding a collective expression of working-class resistance and struggle. Influential Chartists understood perfectly well the significance of culture in the class struggle, staking a claim to literature as a vehicle for proletarian consciousness, composing novels, pamphlets, poems and short stories which placed working-class protagonists at the centre of the narratives (Haywood, 1997). This was needed to contest representations of the working class such as those previously described - the stereotyping of the proletarian, or figuring class inequality in fundamentally moral rather than economic or political terms. Chartist writers adopted instead what Haywood has described as a 'materialist aesthetic' (1997: 9), constituting a political critique of the inequities of capitalism itself.

This countered bourgeois writers' attribution of a moral deficit on the part of the working class, where perceived individual failing substitutes for class structure. In this mode, class can be encoded in terms of individual types and linked more to ideas of status; ideological displacement disguising class realities. Thus, working-class subjectivity might find representation in such typology as the 'rough' and 'respectable', the 'deserving' and 'undeserving', a terminology finding renewed vigour much later (as we shall see) in the quite different conditions of postmodern Britain. For Skeggs, this tendency to define class through culture 'dislocates it from the economic and firmly locates it within the moral, in which representation and visuality become central mechanisms for knowing and identifying the working class' (2004: 40).

\section{From classes to masses: modernity and the rise of affluence}

Entering the 20th century, the logic of commodity exchange began to saturate all aspects of social life. Thus it is that the abstraction of exchange reduced difference to sameness, quality to quantity. And as it was the commodity form which occluded the social relations that brought it into existence, so in turn it worked to disguise the existence of class. Thus we might say that the rise of a mass society, mass culture, the very notion of the masses, came to substitute for the structural imperatives of class as a key focus of attention with regard to social formations. At the same time, the idea of citizenship, consolidating itself within political discourse in the early decades of the 20th century, helped to compound this. Skeggs notes, following Day (2001), that notions of citizenship were formulated in opposition to class, so that in return for political rights, the working class were 'expected to labour for the improvement of the race, the economy and the extension of the empire' (2004: 40). Here, then, class was subsumed under notions of both the masses and the nation; invoking common interests 
grounded in consumption or national identity can effectively displace consideration of inequality and conflict. But references to the rise of the masses, mass culture or modernity - categories variously used by detractors and supporters alike - still constituted ways of talking about class.

The idea of a mass consumer culture reached fruition in the postSecond World War period in western societies. This is a formative moment historically, and Skeggs' analysis moves from the immediate postwar period to examine how its legacies are played out in the contemporary postmodern moment, in which class as an analytical category becomes rejected across a range of disciplines and domains. She detects a whole series of discourses, within recent cultural, political, legal and sociological theory, which work to erase or displace class - particularly the working class - from the agenda. This constitutes what Raymond Williams (1977) would define as a newly-emergent structure of feeling, although ironically enough, one not shorn of its own class affiliations because for Skeggs, those theorizing the end of class in the 1980s and 1990s do so from their largely unspoken class locations as part of a metropolitan élite. They do this by embracing and instituting a new and pervasive ideology of the individual, one predicated on the postmodern dispensation which sees the fragmentation of the social and thus of class formations, and the rise of consumer society. Skeggs is rightly critical of this, and we will return to her argument here in a moment. First, it might be worth exploring the view that this proclamation of the death of class is nothing particularly new.

Notions of the end of class have been a recurring feature in British social theory and cultural commentary for decades, its articulation often marked by periods of rapid economic, technological or political change. Indeed, the period in Britain from the late 1950s into the 1960s witnessed a whole new stress on classlessness, mobility and individualism as a dominant structure of feeling. The context was the development of the welfare state, raising working-class living standards and producing what commentators on both sides of the political divide coded as the 'age of affluence'. As a response, the language or rhetoric of class took a significant new turn away from a focus on political contestation and economic inequality, conditions powerfully articulated in the economic slump of the 1930s. Notions of the working class as a political reality with the potential to transform society shifted to a stress on cultural and political consensus, which witnesses the very subjectivity of class subordinated to the mass-marketed sense of class as 'style', an identity fixed on coordinates provided by the cultural logic of consumption. Discussing the literature of the period, Gary Day argues that 'the art of the 1950s and 1960s focused more on the working class than the middle class', although this particular attention was 'directed to working-class culture, thereby eclipsing its political and economic relations with the middle class' (2001: 180), thus diluting the significance of class in any meaningful (i.e. political) sense. Studies began to take the working 
class as their object of concern, but in the context of decline or demise: an emergent narrative orientation documenting the waning of workingclass community, deprecating the dubious pleasures of popular culture or celebrating the rise of affluence.

Richard Hoggart's seminal text of the period, The Uses of Literacy (1957), somehow manages to do all three of these things at once. It was Hoggart's contention there that the moral economy of prewar workingclass culture, the solidarity and collective care of these communities, had become increasingly undermined by relative affluence and the mass culture of the 1950s 'candy-floss world'. Hoggart's text became a key reference point for others working in this and complementary fields of analysis, and a number of significant themes and positions explored by Hoggart also found articulation in literary forms. Hoggart's focus was on these widespread changes and how they were reflected in, and altered important aspects of, working-class life. His narrative strategy established a contrast between the prewar and postwar periods, and the thrust of the narrative asserts that the changes wrought in the period of welfare - in particular the explosion of mass cultural forms directed at an 'affluent' working-class audience - were eroding the fundamental values and moral economy of working-class life. As a way of grounding his argument, Hoggart invoked 'personal experience' as the measuring rod for his findings. His 'authentic' working-class background was trailed as an index of the purported validity and accuracy of his views, analyses and observations. Such an intervention, with its primary focus on working-class culture, operated to confirm both the existence and disappearance of the working class.

More strictly sociological treatises pursued a similar thread. Mike Savage (2000) suggests that in such work we see a 'critical turning point in the elaboration of the idea that individualized identities were gaining prominence and that these spelled the erosion of class loyalties' (2000: 23-4). Major sociological work on class emerges, he argues, reflecting a fundamental change in the social, economic and cultural condition of Britain; in this perspective, traditional class identities couched in terms of solidarity yield to an instrumentalist or individualistic structure of feeling. Embourgeoisment or affluence and political de-alignment become the dominant themes in sociological discussion around working-class identity. Hoggart's take on working-class collectivism must be seen in this context also. His work spoke of the decline of working-class values and ways of living dominant in the inter-war years, prior to mass commercialization and the development of what he bemoans as 'the candy-floss world'. At the time this became a very powerful and influential argument. Raymond Williams countered a year later with the publication of Culture and Society (1958).

Savage suggests that both these writers' views on working-class culture (and the work of sociologists such as Goldthorpe and Lockwood, in their 
famous study of the affluent worker, whom he identifies in this cluster) derive not necessarily from some objective analysis of the situation but from an underlying political project or perspective - so that in this scenario, the working class become mere containers for the political hopes of some on the Left who are nostalgic for revolution. Skeggs (2004) condones this point, suggesting that in this context class works not only to shape academic debate but almost to frame an academic identity, while in turn fixing a particular image of working-class formations.

To support his argument, Savage quotes Williams from Culture and Society. There, Williams speaks of working-class culture as consisting of the 'basic collectivist idea'. Williams suggests further that 'working-class culture, in the stage through which it has been passing, is primarily social (in that it has created institutions) rather than individual' (1958: 327). This basic collective idea - the dominant structure of feeling characteristic of working-class culture - is contrasted with middle-class individualism. In trying to counter the notions of working-class individualism widespread at the time that Williams was writing, Savage sees Williams turning towards its contrary - a position Savage regards as equally 'mythical' as the newly emerging ethos of individualism.

However, Williams is not arguing here that the working class embodies these sentiments in some complete and uncomplicated form; rather that the institutions of the working class enshrine them. In his argument, conflict exists through a clash of values at a number of social levels - and for Williams, the possibility of spreading the 'collective idea' throughout society is still a very real one, and the most likely route to establishing a participating democracy on a more egalitarian scale - what he calls a 'common culture'. His formulations do not necessarily derive from an unspoken political interest or concealed agenda, using the working class as some kind of cipher for a radical critique or future utopianism, as Savage seems to suggest. Williams' views on working-class culture and identity derive essentially from his assessment of two factors: the altered postwar situation, through which ideas of classlessness were becoming a new common sense; and, more importantly, his own lived experience of being brought up in a rural working-class community within certain, clear labourist traditions. So his stress on the importance of institutional frames - institutions that defend collectivist values - did not necessarily demote the importance of individual identities in the process. Indeed, this is implied in Williams' own assertion in Culture and Society, that 'there is no such thing as masses, only ways of seeing people as masses' (1958: 333).

However, what was occurring was a shift of emphasis in writing about working-class life; a shift characterized by a move towards the sphere of culture. Both Hoggart and Williams help to set an agenda for working-class studies in the following years, but it appears to be one that increasingly marginalized the economic dimension of class experience and process. 
In this same article Savage puts forward the notion of rugged individualism as a means of deconstructing the twin notions of individualism/ instrumentalism and collectivism/solidarity which he perceives as a false, yet pervasive, dualism within sociological and cultural studies discourse. Savage's concept throws up the interesting proposition that workers used the notion of individuality and independence to articulate a sense of dignity, autonomy and pride and, in some cases, class awareness and association, something completely missed by theorists or proponents of individualism. Savage invokes an example of working-class fiction from the period to which he refers, namely Alan Sillitoe's Saturday Night and Sunday Morning (1958) and the novel's main protagonist, factory worker Arthur Seaton. This was one of many novels of the time to explore in detail the changing conditions of working-class life: others included John Braine's Room at the Top (1957), David Storey's This Sporting Life (1960) and Stan Barstow's A Kind of Loving (1960). Each of these works focused on the male working-class figure, newly affluent and on the make. Seen in this light, it might appear that that they confirm, even celebrate, the ideology of affluence and individualism.

Savage's example of Sillitoe's fictional character, Arthur Seaton, is telling, however. Arthur revels in his difference from others, and this is expressed both through his skill at the lathe and his sexual prowess in the bedroom. However, that this foregrounds Arthur's individualism does not cancel out any sense of a collective consciousness, neither does the narrative sideline the significance of the workplace and economic class relations as constitutive of self. Arthur's identity is shaped in part through the narrative's 'inner voice discourse', a dialogism signifying a class consciousness and perspective couched very much in the language of 'us' and 'them'. Thus the dualism that Savage highlights collapses in the character of Arthur, and consciousness emerges as neither one thing nor the other - neither straightforward collective identification nor selfcentred individualism. Moreover, Arthur's job at the lathe remains absolutely central to him - work is not denoted in some simple instrumentalist sense but as a mode of identity, a means of livelihood and a way of living. This is encapsulated in a key moment from the text:

Arthur reached his capstan lathe and took off his jacket ... He pressed the starter button, and his motor came to life with a gentle thump. Looking around, it did not seem, despite the infernal noise of hurrying machinery, that anyone was working with particular speed. He smiled to himself and picked up a glittering steel cylinder from the top box of a pile beside him, and fixed it into the spindle. He jettisoned his cigarette into the sud-pan, drew back the capstan, and swung back the turret onto its broadest drill. Two minutes passed while he contemplated the precise position of tools and cylinder; finally he spat onto both hands and rubbed them together, then switched on the sud-tap in front of the moveable brass pipe, pressed the button that set the spindle running, and ran in the drill to a neat chamfer. Monday morning had lost its terror. (Sillitoe, 1958: 25-6) 
Arthur takes pride in his work, if at times articulating an angry alienation from it. Even so, the image here of his limited control over the process of production is a complex and convincing one, leading one critic to suggest that 'Arthur does not live in spite of his work, he lives through it' (Hitchcock, 1989: 66). It is an image that gets beyond the easy stereotype of the 'alienated worker' or the consumer-oriented 'prole' of much affluence rhetoric, underlining in a far richer way than some of the sociological or cultural commentaries of the time how the workplaceas a necessity, but also a mode of identity-formation - continues to shape working-class lives.

Around this time, the theme of classlessness was taken up from another direction through the auspices of the Centre for Contemporary Cultural Studies at Birmingham, under the stewardship of Stuart Hall. The Centre was influenced powerfully by the work of Raymond Williams and Richard Hoggart, as well as the historical studies of E.P Thompson. Thompson's work on working-class cultural practice and resistant strategies found in The Making of the English Working Class (1963) resonated in the Centre's own focus on cultural forms and symbolic resistance. This developed into the work on subcultures in the 1970s, which explored subcultural modes of resistance to the hegemonic bloc by working-class youth who in various ways reinscribed the trinkets of the mass marketplace into the language of class. This constituted a different response to ideas of affluence and the importance of 'style' referred to previously. It is possible to identify two trajectories within this emerging discursive formation: first, such work enabled cultural studies to open out and explore other areas of concern, such as the media and film; and identities not solely predicated on class, such as gender, 'race' and sexuality. Second, and more negatively, studies such as Dick Hebdige's Subculture (1979) might be regarded as precursors to the kind of cultural populism increasingly evident in postmodern cultural studies of the 1980s. In the 1975 collection Resistance Through Rituals (Hall and Jefferson, 1975), the writers claim to produce work that shows the life of a 'group or class ... the meanings, values and ideas embodied in institutions, in social relations, mores, customs, in the uses of objects and material life' (1975: 10). Culture is pluralized and becomes cultures where identity finds expression through symbolic modes invariably tied up with the culture industries and a burgeoning commodity culture. On one level these studies attempted to negate the discourses of classlessness and individualism by stressing collective experience. Yet these working-class subcultures appear to exist anywhere but in the workplace - with the exception of Paul Willis' detailed study of how working-class kids get working-class jobs, in Learning to Labour (1977) - so it could be argued that to get a clearer idea of how the newly affluent postwar working class engages the dialectic of work/leisure and factory/football pitch, a reading of Sillitoe's Saturday Night and Sunday Morning would be more rewarding. 


\section{The return of the individual and the rise of identity politics}

The return of mass unemployment to Britain in the 1980s destroyed much of the working-class culture on which some of the subcultural critique was predicated. Areas of heavy industry were decimated and whole communities collapsed. This saw a wider probing of the significance of class: a more thoroughgoing questioning than seen hitherto, leading to a changing focus of attention away from class formations towards new social movements. As a general shift towards postmodern frames of reference gained ground, the material realities of class embodied in modes of work and association and the subjective sense of class identity expressed in the consciousness of class and attendant 'structures of feeling', came to be seen as belonging to a different, earlier period in socio-economic history. The rhetoric of classlessness embedded in the 1950s and 1960s, based around the notion of affluence, capitulates to a widespread rejection of the language of class as a way of understanding social experience and formulating political strategy. The consolidation of a radical individualism as a hegemonic ideology characterized the rise of neo-liberalism, particularly in Britain and the United States, under the auspices of Thatcher and Reagan. From 1980 onwards the New Right dominated the political terrain, articulating subjectivity definitively in terms of consumption rather than production, a deep shift designed in part as a way of eroding class consciousness or identification based on coordinates of work-based identity and community. This new individualism seemed oddly commensurate with poststructuralist or postmodernist suspicions of class as a master narrative purportedly homogenizing all identities under its sign, and its further claims, developed in some quarters, centred on the essential fluidity of the ontological boundaries of subjectivity. Instead, a combination of de-industrialization and Thatcherite neo-liberalist economics was seen as producing a consumer utopia where individuals might coexist on some purported axis of equivalence. The old language of class had no purchase on this terrain. Thus it turns out that resistance was found only on the margins, where the new social movements might come to constitute a counter-hegemonic formation.

But the 'militant-particularisms' of identity politics - the new social movements - allow scant space to class. These identities are seen as grounding themselves in cultural terms, but are based themselves on modes of exclusion and inclusion, so that some cultures can be seen as more "progressive' than others. Nevertheless, this orientation towards identity politics established itself as the new 'common sense' within radical political and social theory, with a stress on the need to extend entitlements beyond 'economic, political and social rights ... to the cultural, with the assumption that in some way we may speak of the cultural rights of citizenship' (McGuigan, 1996: 138). The politics of 'race'/ethnicity, gender and sexuality would have the necessary effect of privileging long-silenced or 
marginalized voices, but it also had the (perhaps) unintended consequence of dislodging former concerns with class. Cornel West has summed up identity politics in the following way:

Distinctive features of the new cultural politics of difference are to trash the monolithic and homogeneous in the name of diversity, multiplicity and heterogeneity; to reject the abstract, general and universal in light of the concrete, specific and particular, and to historicise, contextualise and pluralise by highlighting the contingent, provisional, variable, tentative, shifting, and changing. (West, quoted in McGuigan, 1996: 138)

The oppositions articulated here have a very clear hierarchy of their own, however, suggesting that any discourse or practice inclined towards universalist ideals in particular must be abandoned in favour of plurality, contingency, the heterogeneous. The developing tendency to celebrate 'difference' will have contradictory results though, when applied to understandings of class and associated issues around economic and political inequality and exploitation. Indeed, for one commentator, the whole issue of class within the postmodern moment becomes little more than the 'forgotten identity of identity politics' (Medhurst, 2000: 23). There was some attempt to counteract this in the work of women scholars from the late 1980s into the 1990s. Carolyn Steedman's Landscape for a Good Woman (1986) explored powerfully the interrelationship of class and gender. Other studies by Kuhn (1995), Skeggs (1997) and Walkerdine (1991) sought to place working-class subjectivity back on the academic agenda at the precise moment that its very existence was being bought into question.

Skeggs (2004) highlights the curious exclusions of identity politics. Thus, not all cultures are regarded as equal: indeed, some cultures just cannot cut it, are in key ways fundamentally regressive, and come increasingly to be coded as those aligned to the working class. This leads to forms of segregation and a kind of apartheid. In this context, Skeggs notes the interesting shift in recent times regarding the image of the male industrial worker. She contends that the fascination of subcultural theorists and cultural commentators with the white working-class male in the 1960s and 1970s has declined, although this fascination was always double-edged. Out of this interest came an image of 'the heroic hard physical worker, a repository of everything the middle class did and did not want to be, but also potentially racist, fascist, authoritarian, undisciplined and ignorant' (2004: 98). We might add, in the current context of post-industrialization in the West, that this figure is viewed now simply as in the way, redundant, superfluous to requirements.

Perhaps more pervasive is what Skeggs defines as the "new individualism', articulated through concepts of mobility, reflexivity and cosmopolitanism. This ideology of mobility or reflexivity is found in the work of key sociologists such as Ulrich Beck and Anthony Giddens. It denotes a kind of self-authoring subject who is free, it seems, from any wider structural 
constraints, such as the ascriptions of class. Partly these arguments turn on the notion of the 'optimising individual' (2004: 62) with the capacity to invest in themselves and thus profit in the socio-economic marketplace which, in turn, suggests a neutral, equal terrain on which everyone has the opportunity to prosper. Using one's economic and cultural assets in this way, one can be seen to avoid exploitation and in the process become a 'subject of value' for oneself (2004: 71). But Skeggs insists that not everyone has privileged access to the 'new individuality' (2004: 56), and if we do not accept the idea of this level terrain on which such arguments must rest, then it becomes self-evident that the poor have no chance of becoming subjects of value because they remain deprived of 'access to the resources required to produce themselves as such' (2004: 71). For Skeggs, this means that the concept of exploitation - here broadened to signify the use of cultural power as well as economic - still holds good, structuring the social in fundamental ways. The self-fashioning of the 'enterprising self' only assumes 'a level playing field, in which access to assets are available to all' (2004: 73). Moreover, it might be argued that, in the context of the new economy and workplace identities, this notion of the 'enterprising self' - a rather fancy term for 'getting on' - merely reworks a familiar notion from the 1970s but without its critical aspect: Willis' (1977) concept of 'learning to labour'.

For Skeggs, the stress on the individual has intensified into a kind of compulsory individualism. Class is rejected as an essentialist mode of thinking inadequate for new times; an identity ascribed rather than acquired. But it is possible to read this position entirely in class terms. Located in the intellectual and academic élite, these arguments remain grounded materially in class interests, disseminated by a professional, well-educated middle class in whose interests they are developed. As 'middle-class movements' (Milner, 1999: 54), they show scant concern in contesting the class-divided nature of a late-capitalist society in which they are handsomely rewarded. If such rewards occur chiefly through processes of market commodification and consumption, then so be it. Thus we see the 'new individualism' in large part driven by a consumerist ethic. When we make ourselves, we make choices; self-fashioning is repackaging or rebranding; value and investment in the self implies marketable goods with varied equivalents. Skeggs suggests, correctly, that the theories of both Beck and Giddens do little more than 'reproduce the consumer market rhetoric that not only promotes individualism as necessary, but also makes it a moral prerogative' (2004: 57). Such approaches leave the working class - particularly those designated as the underclass - in a particular predicament, seen to be holding no assets at all, whether cultural, symbolic or economic. In this context, then, the white working class has

been used as symbols of a generalized 'backwardness', a constitutive limit, 
modern' and in a moral category referring to liberal, cosmopolitan, work and consumption-based lifestyles and values. (2004: 150)

What are the ways in which this process occurs in our times? As Skeggs' arguments make clear throughout, representation is key. Making the working class visual for consumption has a long historical pedigree, as has been shown already. Today, television provides a wide window into the working-class world. Many of these programmes focus on notions of personality, or what Skeggs (2004) calls 'personhood'. Once again, this reflects a displacement of class, class issues and class categories into a concentration on the individual's personality traits: personal relations that, for example, are in no way tempered, determined or shaped by the imperatives of working lives - public selves are effectively and consistently subordinated to the private self of consumption and self-fashioning. What seems to dominate in many of these stories is the development and representation of the charismatic, aberrant or abject individual (or sometimes family). As we have seen, this tendency to individualize and pathologize class is not new; through them, class is figured culturally and morally. But where working-class subjectivity is concerned, invariably it is as bad culture, in some sense lacking, and commentaries on this emerge in moralizing terms, as is evident in current drama, drama documentary or reality $\mathrm{TV}$.

The rhetoric of social exclusion and, more specifically, the notion of the underclass, plays a key role here. Underclass discourse takes in a range of groups - in reactionary guise these can include long-term welfare recipients, single parents, even certain ethnic groups. Underclass discourse is pernicious in the way that it both denies and speaks class simultaneously, and this serves a purpose for the middle class. For Skeggs, it serves to establish a distance - a kind of 'spatial apartheid' (2004: 180) - the necessary space through which middle-class value, virtue and worth is expressed in opposition to lower-class indulgence and moral negligence. Moreover, an equally insidious effect of the underclass category is to produce the very familiar condition of divide and rule within working-class formations themselves. Entering the public imaginary, underclass discourses can be found in a range of forms: programmes such as 'factual' documentaries on television, often utilizing closed-circuit TV (CCTV) footage,

unleash a chain of signifiers in which an underclass is not only represented, but also shaped by disparate discourses of familiar disorder and dysfunction, dangerous masculinities and dependent, fecund and excessive femininities, of anti-social behaviour, and moral and ecological decay. (2004: 87)

Arguably, it is in this context that Zygmunt Bauman (1998) can talk about a dynamic that he labels 'adiaphorization'. This concept implies a process through which the privileged lose any moral obligation or sense of responsibility towards the poor and deprived, thus ceasing to identify 
with them in any meaningful way, thereby guaranteeing that such conditions persist. Elements of the working class become the Other and the new 'enemy within': incapable of or resistant to work, amoral and excessive in their public and private behaviours; an unsightly sore on the anatomy of society. This structure of feeling is reinforced and disseminated in a range of ways - Skeggs has pointed to 'factual' television and the recent phenomenon of 'chavs', but we could highlight also, in a British context, such television comedy dramas as The Royle Family and Shameless, shown on BBC Two and Channel 4 respectively (one could add Little Britain to this list). Both series expose the working class and unemployed (those generally labelled an underclass) to the middle-class gaze through a set of discourses which seem likely to perpetuate and confirm the very prejudices of those who despised them in the first place.

For adiaphorization to exist such spectacles need to be produced, as does the mobilization of periodic 'charity-fests' which, as Bauman (1998) suggests, have a particular function here. He sees these public displays as events in which the middle class and petty bourgeoisie willingly engage, using them as a way of dealing with the remnants of moral impulse or obligation - residual feelings that threaten to seep in further. The power bloc thus effectively addresses those impulses in this way, securing hegemony. This represents another example of how class manifests itself through symbolic modes of exploitation - in this case moral, cultural and in the end, as it reinforces relationships of inequality - economic.

\section{Conclusion}

So where does this leave the working class? Discussing class in the US, Slavoj Žižek (2004) makes an important point, one relevant to this discussion. In examining the rise of republican populism in the US, and the rejection of the liberal Left and its espoused politics of multiculturalism by large

sections of the working class, Žižek sees a contradiction between the political goals of feminists, anti-racists and other new social movements generally (largely supported by liberals and democrats) and the objectives of class struggle, often defined by these same liberals as 'old' politics, beyond the terms of an irreversible globalization agenda and 'modernization' process. Žižek claims that

although feminism can be articulated with class struggle for emancipation of the lower classes ... it can (and certainly does) function as an ideological tool of the upper middle classes used to assert their superiority over the supposedly patriarchal and intolerant lower classes. (2004: 20)

Moreover, he suggests that the essential aim of new social movements is to 'translate antagonism into difference', seeking 'peaceful co-existence' in the name of a cultural plurality. However, he argues that class struggle 
works with a different logic, which strives 'to aggravate class differences into class antagonisms' (2004: 20). Therefore, to

set up a series of equivalences between race, gender and class is to obscure the peculiar logic of class struggle, which aims at overcoming, subduing, even annihilating the other - if not its physical being, then at least its socio-political role and function. (2004: 20)

The upshot of this is that it becomes difficult for identity politics to accommodate class, which leads to its marginalization in such discourses. This de-recognition of class, and class struggle, has the effect of debilitating the working class both in terms of the politics of cultural recognition and questions of political and economic justice. (In truth, this is more salient to concerns of class than cultural questions, although it could be argued that the two cannot or should not, indeed need not, be separated.) It is in this contradiction - within the paradoxes of identity politics, or the politics of the self-fashioning subject, or the prosthetic self - that the working class loses its voice, becoming a signifier merely to bolster the cultural prestige of other, more powerful, groupings: those who can shape their identity in opposition to the necessary and constituting Other, so that 'the cultural fundamentalism and the abject agency attributed to the working-class in the UK, Europe and US ... renders it 'the enemy within' (Skeggs, 2004: 180).

There is a double-bind looming here. How do working-class groups, whose exploitation now goes beyond the extraction of surplus value at the point of production (it always did, in fact) and filters into a range of other exploitative modes within the realm of culture and the cultural the making of the middle-class self through constructing a downmarket Other - challenge this condition? Skeggs (2004) refers briefly in her analysis to working-class modes of resistance, but provides scant details of such practices in action. Indeed, she suggests that contesting those pervasive rhetorical devices which negatively construct working-class subjectivity will achieve little beyond confirming the process itself. Indeed, this reflects a tendency within the book as a whole to depict the working class not so much as subjects, but as subjected - perennial prey to those middle-class strategies of representation and appropriation. Besides, the working class has little access to the institutional sites that reproduce these representations and practices in the first place, and in the economy of a discursive hierarchy shaped elsewhere, is given very little legitimacy anyway in terms of value, if its voice is heard. It may well be that class struggle is fought through culture, but it may be the case also that it is a site on which the working class cannot effectively compete.

All the same, Skeggs ends by insisting on the need to 'reinvigorate class analysis' and develop an understanding that goes beyond the economic to an awareness of the 'consequences of cultural struggle' and its implication in processes of 'appropriation, exploitation and governance' (2004: 186). 
Perhaps there is a need, as another critic suggests, to acknowledge the 'primacy of class analysis over the various types of identity politics manifest in gender, race and sexuality', not because these positions are of no relevance (they certainly are, and their intersection with the politics of class will be essential for any reinvigoration of class analysis), but because 'class provides an account of the origin of inequality from which other forms of oppression arise' (Day, 2001: 18). For Raymond Williams there was 'no getting beyond class politics', and the issues raised by new social movements would lead inevitably 'into the central systems of the industrial-capitalist mode of production and ... its system of classes' (Williams, 1983: 178-9). Indeed, it is the site of the economic where the working class is, or should be, most visible - at its strongest and most vulnerable, simultaneously. This accounts for the tendency within middle-class discourse on class, going as far back as the 19th century, to discount, displace or simply mystify economic relations, not to mention employ strategies to weaken and attack working-class institutions - those necessary institutional sites flagged up long ago in Culture and Society by Williams (1958), spaces through which working-class identities might be voiced and celebrated. This relates to the question of recognition and worth and it is an important one; how such recognition might find channels of articulation is more important still. Without creating, sustaining and strengthening the working-class institutions (trade unions, political parties, community groups) that empower working-class people as they go about their everyday lives, the hidden - and not so hidden - injuries of class will continue.

\section{Acknowledgements}

I would like to thank the two anonymous reviewers for their helpful comments on this article. The article comes in part out of work on the ESRC funded Identitities and Social Action Programme, and the project 'Does Work Still Shape Social Identities and Action', RES148-25-0038. The article has benefited greatly from conversations with colleagues working on that project.

\section{References}

Barstow, S. (1960) A Kind of Loving. London: Michael Joseph.

Bauman, Z. (1998) Work, Consumption and the New Poor. Buckingham: Open University Press.

Braine, J. (1959) Room at the Top. London: Harmondsworth.

Brontë, C. (1991[1849]) Shirley. Oxford: Oxford University Press.

Cannadine, D. (2000) Class in Britain. New York: Yale University Press.

Carey, J. (1992) The Intellectuals and the Masses: Pride and Prejudice among the Literary Intelligentsia, 1880-1939. London: Routledge.

Day, G. (2001) Class. London: Routledge.

Dickens, C. (1985[1854]) Hard Times. London: Penguin.

Eliot, G. (1980[1866]) Felix Holt. London: J.M. Dent \& Sons. 
Gaskell, E. (1981[1848]) Mary Barton. Oxford: Oxford University Press.

Goldthorpe, J.H., D. Lockwood, F. Bechhofter and J. Platt (1968) The

Affluent Worker: Industrial Attitudes and Behaviour. Cambridge: Cambridge

University Press.

Hall, S. and T. Jefferson (eds) (1975) Resistance Through Rituals: Youth SubCultures in Post-War Britain. London: Hutchinson.

Haywood, I. (1997) Working-Class Fiction: From Chartism to Trainspotting. Plymouth: Northcote House.

Hebdige, D. (1979) Subculture: The Meaning of Style. London: Methuen.

Hitchcock, P. (1989) Working-Class Fiction in Theory and Practice: A Reading of Alan Sillitoe. Ann Arbor, MI: UMI Research Press.

Hoggart, R. (1957) The Uses of Literacy: Aspects of Working-Class Life, with Special Reference to Publications and Entertainments. London: Chatto \& Windus.

Huyssens, A. (1988) After the Great Divide: Modernism, Mass Culture and Postmodernism. London: Macmillan.

Kuhn, A. (1995) Family Secrets: Acts of Memory and Imagination. London: Verso.

McGuigan, J. (1996) Culture and the Public Sphere. London: Routledge.

Marx, K. and F. Engels (1967[1848]) The Communist Manifesto

(trans. S. Moore). London: Harmondsworth.

Medhurst, A. (2000) 'If Anywhere: Class Identifications and Cultural Studies Academics', in S. Munt (ed.) Cultural Studies and the Working Class: Subject to Change, pp. 19-36. London: Cassell.

Milner, A. (1999) Class. London: Sage.

Savage, M. (2000) 'Sociology, Class and Male Manual Work Cultures', in A. Campbell, N. Fishman and J. McIlroy (eds) British Trade Unions and Industrial Politics VII: The High Tide of British Trade Unionism 1964-1979, pp. 23-41. London: Ashgate.

Sillitoe, A. (1958) Saturday Night and Sunday Morning. London: Longman.

Skeggs, B. (1997) Formations of Class and Gender: Becoming Respectable.

London: Sage.

Skeggs, B. (2004) Class, Self, Culture. London: Routledge.

Smiles, S. (1859) Self-Help. London: Murray.

Stallybrass, P. and A. White (1986) The Politics and Poetics of Transgression. London: Methuen.

Steedman, C. (1986) Landscape for a Good Woman: A Tale of Two Lives. London: Virago.

Storey, D. (1960) This Sporting Life. London: Longmans.

Thompson, E.P. (1963) The Making of the English Working Class. London:

Penguin.

Walkerdine, V. (1991) Schoolgirl Fictions. London: Verso.

Williams, R. (1958) Culture and Society. London: Hogarth Press.

Williams, R. (1977) Marxism and Literature. Oxford: Oxford University Press.

Williams, R. (1983) Towards 2000. London: Chatto \& Windus.

Willis, P. (1977) Learning to Labour: How Working-Class Kids Get Working-

Class Jobs. London: Routledge and Kegan Paul.

Žižek, S. (2004) 'Over the Rainbow', London Review of Books (4 Nov.): 20. 


\section{Biographical note}

John Kirk is a research fellow at the Working Lives Research Institute, London Metropolitan University. He has published widely on British working-class writing and culture and is the author of Twentieth Century Writing and the British Working Class (University of Wales Press, 2003) and Class, Culture and Social Change: On the Trail of the Working Class (Palgrave, forthcoming). A D D R E S S: Working Lives Research Institute, London Metropolitan University, 31 Jewry Street, London EC3N 2EY, UK. [email: john.kirk@londonmet.ac.uk] 